\title{
$71(2031)$
}

\section{Studies on lung volume. V. Quantitative influence of certain factors on admixture.}

\section{By CHRISTEN LUNDSGAARD and KNUD SCHIERBECK.}

[From the Medical Clinic of the University of Copenhagen, Denmark.]

In establishing a complete mixture of air within the lungs with other air several factors come into play. Some of these factors play a minor role and may be varied within rather wide limits before any appreciable influence on the results is observed. Others are of more importance, but their variations can be kept within narrow limits and therefore neglected. There are, however, three factors, which mainly govern the procedure of mixing: first, the number of times rebreathing takes place; second, the depth of the respirations; and third, the amount of air left in the lungs after expiration, that is, the amount of air which can be mixed through diffusion only. The methods where mixture is used, or the subjects on whom these methods are applied, often prevent us from choosing the magnitude of these which would be most suitable for obtaining a complete mixture. In a series of experiments, an example of which are reported in this paper, we have investigated the quantitative influence of variations in these three factors.

Technique. All our experiments are performed on two normal, well trained subjects. We have, for the sake of convenience, exclusively used hydrogen plus oxygen, but earlier experience makes it highly probable that the results can be extended to oxygen, to carbon monoxide, and to nitrous oxide.

A certain varying amount of hydrogen plus oxygen was introduced into a bag or into a Krogh spirometer. The subject started to inspire with a known amount of air left in his lungs. The minimum amount of air left within the lungs was of course the residual air. By starting from different points a known fraction of the reserve air or even of the complimentary air could be added to the residual air. The air left in the lungs was 
varied from 1.35 liters to 6.35 liters. Similarly the depth of the respirations, kept constant during an experiment, could be varied regularly from one experiment to another. The whole range was from 1 to 5 liters. The third factor, the number of respirations was varied from 2 to 16 . At the end of each experiment the subject expired to the maximum extent and samples were drawn (1) from the bag, and (2) from alveolar air. According to previous investigations a higher hydrogen percentage in the alveoli than in the bag was taken as a proof of full mixture. Table I is an example of one series of 110 experiments. Table II gives all the results in a concentrated form.

TABLE I.

Example of experiments. Complete mixture is present if $b=$ or $>a$.

\begin{tabular}{|c|c|c|c|c|c|c|}
\hline $\begin{array}{c}\text { Experi- } \\
\text { ment } \\
\text { number. }\end{array}$ & $\begin{array}{l}\text { Amount of } \\
\text { air left in } \\
\text { lungs after } \\
\text { expiration. }\end{array}$ & $\begin{array}{l}\text { Depth of } \\
\text { respira- } \\
\text { tiono. }\end{array}$ & $\begin{array}{c}\text { Number of } \\
\text { respira. } \\
\text { tions. }\end{array}$ & $\begin{array}{c}\text { Hydrogen } \\
\text { in oample } \\
\text { from } \\
\text { spirometer } \\
\text { (or bag). } \\
a\end{array}$ & $\begin{array}{c}\text { Hydrogen } \\
\text { in ample } \\
\text { from } \\
\text { alveolar air. } \\
\quad b\end{array}$ & $\begin{array}{c}\text { Difference } \\
\text { between } \\
\text { two } \\
\text { samples. } \\
b-a\end{array}$ \\
\hline & liters & liters & & per cent. & per cent. & \\
\hline 1 & 4.85 & 1.5 & 9 & 11.97 & 11.90 & -0.07 \\
\hline$\overline{2}$ & 4.85 & 1.5 & 10 & 6.32 & 6.36 & +0.04 \\
\hline 3 & 4.85 & 2.0 & 6 & 7.50 & 7.43 & -0.07 \\
\hline 4 & 4.85 & 2.0 & 7 & 9.28 & 9.29 & +0.01 \\
\hline 5 & 4.85 & 3.0 & 4 & 9.54 & 9.48 & -0.06 \\
\hline 6 & 4.85 & 3.0 & 5 & 11.06 & 11.00 & -0.06 \\
\hline 7 & 4.85 & 3.0 & 6 & 10.82 & 10.82 & \pm 0.00 \\
\hline 8 & 3.85 & 1.5 & 5 & 15.25 & 14.90 & $=0.35$ \\
\hline 9 & 3.85 & 1.5 & 6 & 11.51 & 11.51 & \pm 0.00 \\
\hline 10 & 3.85 & 1.5 & 7 & 16.01 & 16.03 & +0.02 \\
\hline 11 & 3.85 & 2.0 & 5 & 9.12 & 8.91 & 0.21 \\
\hline 12 & 3.85 & 2.0 & 6 & 13.15 & 13.17 & +0.02 \\
\hline 13 & 3.85 & 3.0 & 4 & 10.15 & 10.05 & -0.10 \\
\hline 14 & 3.85 & 3.0 & $\tilde{5}$ & 10.60 & 10.60 & \pm 0.00 \\
\hline 15 & 3.85 & 4.0 & 2 & 10.47 & 10.13 & $=0.34$ \\
\hline 16 & 3.85 & 4.0 & 3 & 12.94 & 12.91 & -0.03 \\
\hline 17 & 3.85 & 4.0 & 4 & 10.29 & 10.30 & +0.01 \\
\hline 18 & 3.85 & 4.0 & 5 & 16.52 & 16.52 & \pm 0.00 \\
\hline
\end{tabular}


TABLE II.

Relations between amount of air left in lungs after expiration, depth of respiration and number of respirations in experiment giving full mixture of lung air with hydrogen in two normal individuals.

\begin{tabular}{|c|c|c|}
\hline $\begin{array}{l}\text { Amount of air left in- } \\
\text { side lungs after ex- } \\
\text { piration (residual air } \\
\text { plus more or less of } \\
\text { vital capacity). } \\
\text { liter }\end{array}$ & Depth of respirations. & $\begin{array}{l}\text { Number of respirations } \\
\text { necessary for secur- } \\
\text { ing full mixture. }\end{array}$ \\
\hline \multicolumn{3}{|c|}{ (a) Rebreathing from a Krogh spirometer. } \\
\hline 6.35 & 1.5 & 14 \\
\hline 5.85 & $\left\{\begin{array}{l}1.5 \\
2.0\end{array}\right.$ & $\begin{array}{r}13 \\
7\end{array}$ \\
\hline 4.85 & $\left\{\begin{array}{l}1.5 \\
2.0 \\
3.0\end{array}\right.$ & $\begin{array}{r}10 \\
7 \\
6\end{array}$ \\
\hline 3.85 & $\left\{\begin{array}{l}1.5 \\
2.0 \\
3.0 \\
4.0\end{array}\right.$ & $\begin{array}{l}6 \\
6 \\
5 \\
4\end{array}$ \\
\hline 2.85 & $\left\{\begin{array}{l}1.5 \\
2.0 \\
3.0 \\
4.0 \\
5.0\end{array}\right.$ & $\begin{array}{l}6 \\
5 \\
5 \\
4 \\
3\end{array}$ \\
\hline 2.00 & $\left\{\begin{array}{l}1.0 \\
1.5 \\
2.0 \\
3.0 \\
4.0 \\
5.0\end{array}\right.$ & $\begin{array}{l}9 \\
\mathbf{6} \\
4 \\
\mathbf{3} \\
\mathbf{3} \\
\mathbf{3}\end{array}$ \\
\hline \multicolumn{3}{|c|}{ (b) Rebreathing from five-liter rubber bag. } \\
\hline 2.00 & $\left\{\begin{array}{l}1.0 \\
1.5 \\
2.0 \\
2.5 \\
3.0\end{array}\right.$ & $\begin{array}{l}6 \\
5 \\
3 \\
3 \\
3\end{array}$ \\
\hline 1.30 & $\left\{\begin{array}{l}1.0 \\
1.5 \\
2.0 \\
2.5 \\
3.0\end{array}\right.$ & $\begin{array}{l}\mathbf{7} \\
\mathbf{5} \\
\mathbf{3} \\
\mathbf{3} \\
\mathbf{3}\end{array}$ \\
\hline
\end{tabular}

